\title{
The Foolishness of Living: Georges Henein Between Worlds
}

\author{
Michael Richardson
}

\author{
"The future will have the brilliance and coldness of the \\ scalpel."
}

- Henein L'Esprit frappeur

"The empire of walls is infinite." This Kafkaesque phrase, taken from one of the very first texts published by Georges Henein ("Le Sens de la vie" in Deraisons d'être 1938; Cuvres 55) perhaps defines a task the author set himself at the beginning of his career and never managed to accomplish: to overcome, or at least to challenge the province of, those walls. It was of course a task impossible to achieve, and one whose fulfilment would have been worthless in any event. For Henein recognised, even from an early age, that life was a journey whose destination would never become apparent, and that the purpose of engaging in it would never rise above being an exercise in futility. Indeed life was only this journey, a limited excursion that had to be made significant in its own terms because there was nothing outside of it. The encounter alone existed, the encounter with oneself and with others: "The only true world is the one we create within us; the only sincere world is the one we create out of the others" (De l'Irréalisme in Euvres 40).

Georges Henein, born in Cairo in 1914, who would come to the end of this journey of life in Paris in 1973, was the leading animator of surrealism in Egypt, which flourished there in the years between 1937 and 1952, and a major figure in surrealism internationally. A journalist, a poet and a storyteller, Henein came to surrealism in 1934, at the age of twenty, while studying for his baccalaureate in Neuilly. Already something of a cosmopolitan, or 'Mediterranean', having spent his childhood between Cairo, Madrid and Rome as the son of the Egyptian diplomat Sadik Henein Pacha, Henein has aptly been characterised by Sarane Alexandrian as a "wayfarer of two worlds" (Georges Henein 67). But perhaps it is insufficient to see him as a wayfarer merely of two worlds. As an Oriental in Europe and a European in the Orient, he was simultaneously inside and outside of both traditions; but more than this, as a French-speaking Egyptian from a Coptic family claiming an ancient 
lineage, he was an outsider to the dominant Islamic sensibility of modern Egypt while, as an atheist who married a woman from an Islamic family, he defied both traditions. ${ }^{-}$This in-betweenness gave him an acute sense of the problematic nature of cultural identity and belonging in the twentieth century, but also of the essential otherness (and solitude) of the elemental human condition of existence itself. This is precisely the moral imperative that drew him to surrealism and motivates the entirety of his work. It is also what makes his work of continuing relevance to the situation of the world today as well as providing another of the many facets of experience that have to be explored in order to facilitate our broader understanding of surrealism.

Henein's work cannot be properly appreciated without recognising its essentially moral nature and the extent to which this above all links it to surrealism. The extent to which surrealism was, more than anything else, a moral sensibility tends to be neglected. Indeed, superficial commentators often assume that surrealism was situated beyond morality, a misconception deriving no doubt from Breton's definition (which he subsequently regretted having penned) in the First Manifesto of Surrealism as psychic automatism practiced in a way that would be "exempt from any aesthetic or moral concern" (Breton 26).

Moral concerns were in fact central to the surrealists from the beginning, something that their opposition to the carnage of the First World War and the civilization that had engendered it had concretized through the years of dadaist negativity and the gradual formation of a surrealist sensibility that became fully manifest in 1924. The demand in the first issue of the journal La Révolution surréaliste for "a new declaration of the rights of man" quite clearly sets out the moral nature of the surrealist quest. Indeed, in many ways it might be said surrealism has been one of the few movements to have maintained a moral consistency and instrumentality throughout a century more generally characterised by wantonness and ignominy, although it is, as Henein says, of a negative morality we are speaking, "a morality of contestation, not of affirmation" (L'Esprit frappeur 68). And there were few people who took this moral concern more seriously, or engaged with it at greater length, than Georges Henein, whose major contribution to surrealism has to be considered under this aspect.

The Egypt into which Henein was born was one still under colonial control, and it would not be free from foreign domination until 1952 when an armed coup would establish an independent government but also hand power to the military, an institution Henein considered just as alien to human values, even under the leadership of Gamal Abdel Nasser (the "prince with the semaphore nose," (L'Esprit frappeur 81) as Henein called him), one of the more "enlightened" (if this is not a contradiction in terms) of twentieth-century dictators. His knowledge of diplomatic niceties gleaned from observation as the child of a diplomat presumably left Henein with 
few illusions about the political ruses of the powerful and the possibility of change being effected from within political systems, although he appears to have considered himself a Marxist (of sorts) throughout his life.

Henein recognised too that imperialist domination entailed more than simply exploitation and political rule: it also meant, and perhaps more significantly, cultural subservience, something that affected every part of the social body and which it was the writer's task to combat by making use of the limited set of discourses open to him. Surrealism offered a possible opening up of these discourses, a means of communication between Paris and Cairo specifically, but also more generally between the 'Orient' and the 'West', concepts which Henein appears to have recognised from quite early on as being not geographical entities but as cultural constructions providing mental landmarks within which people subconsciously situated themselves.

The story of Henein's active involvement in surrealism in Egypt has been well told (El Janabi 199; LaCoss). Over this period surrealism made its mark in Egyptian society as a provocation and an irritant to the dominant cultural make-up, but had limited impact in challenging its overall discourse because, as El Janabi cogently expresses it,

The main task in Egypt was to bring to the Arabic language innovation that had the power to liberate it from the tyranny of traditional Koranic structure. An innovation that must, as the early poetical products of surrealism had done to the French language, decipher the hieroglyphics of prefigured patterns of expression, in which the obstacle (i.e. the traditional Aristotelian distrust of invention and imagination) was crystallized. (The Nile of Surrealism 25)

For intellectuals from a Christian background who, moreover, were imbued with ideas of European modernism that could only be treated with suspicion in Egypt, this meant that any initiative they took "would be taken as a Christian intrusion on the privacy of the Islamic spirit, without which the mental structure of Egypt would be inert" (25).

Henein would, however, also play an important role in the re-constitution of the French surrealist group after the war, being principally responsible, along with Henri Pastoureau and Sarane Alexandrian, for writing the key collective text "Inaugural Rupture", issued on 21 June 1947, in which surrealism's anti-Stalinist credentials are set out in no uncertain terms. Yet he would withdraw from it a year later, on 26 July 1948, writing a careful letter to Breton giving his reasons. 2 On 14 June, the surrealists had issued an anti-religious tract, "A la Niche les glapisseurs de dieu." $\underline{3}$ Ramsès Younane, Henein's closest friend in the Egyptian surrealist group, refused to sign this document, apparently considering it too contingent upon earlier surrealist concerns and having no relevance to the issues of the time. Henein did sign it, although he appears to have shared these reservations. ${ }^{4}$ However, what seems to have disturbed Henein was Breton's response to Younane, accepting 
that the tract was disappointing but saying that it was "better than nothing" (Alexandrian, Georges Henein 54). This seems to have concretized Henein's disillusion, which had also been fed by other factors (riding roughshod over reservations made by the groups in London, Bucharest and Cairo about current activities, the publication of an unsatisfactory new journal, Néon, and proposed participation in an exhibition, "Comme," organised by Maurice Baskine) which were not even "better than nothing"; in the eyes of Henein silence would "still be the most advisable surrealist manifestation" rather than these expressions. Indeed, Henein may have seen in this "better than nothing" an echo of the "for want of anything better" he had earlier identified as exemplifying the immediate post-war malaise in general. "You are free," he wrote to Breton, "to congratulate yourself on the number of signatures gained, without being concerned about the meaning of those signatures and 'ulterior motives'” (Alexandrian Georges Henein 55). Breton, indeed, may have taken Henein's letter to heart, having realised that the surrealist group had, as Henein asserted, lost cohesion. This particular tract would contain fifty-two signatories, comprising veterans of the movement from before the war, newcomers who had been galvanized by it through the war experience, and young recruits for whom the war was certainly decisive, but who as adolescents experienced it in a completely different way. Breton may have recognised that this situation called for a clearing of the stables, and in fact within months a series of ructions would decimate the group, cleansing it of virtually all of the old guard and opening up the path for the youngest recruits to re-constitute the group on a more cohesive basis. This would be too late for Henein, but of course he too would have been a member of the old guard, and almost certainly would have not been in sympathy with this new direction taken in any event.

Sarane Alexandrian nevertheless equates Henein's withdrawal from active involvement in the surrealist movement to his own, saying that it was not disillusionment with surrealism as such, but rather the fact that he had reached a stage in his personal evolution that required him to break with the tutelage of Breton and assert his own identity. I agree that Henein's disillusionment was not with surrealism as such (his letter to Breton explaining his withdrawal makes this clear), but I am not convinced that Henein ever regarded himself either as being under Breton's tutelage or as needing to break away from it. Even if this was the case, there seem far more significant reasons for his withdrawal. These were tied to his experience of the war and its immediate aftermath, which was fundamentally different not only from that of Breton but also from any of the French surrealists.

Henein had spent the war years in Cairo, but mention of the war itself is strangely absent from his writings, despite the fact that one of the most decisive battles was fought in Egypt. He appears to have maintained a sense of detachment from it, viewing it from this in-between situation in which 
he found himself: neither of Europe nor of the Orient and yet belonging to both. This allowed him to view it less in terms of its immediacy and more in relation to its broader implications.

It was this that distinguished him not only from Breton himself and those surrealists who had spent the war years in exile, but also from those who had remained in Europe and participated in one way or another in the resistance, as well as from the younger recruits who experienced the war as part of their process of growing up rather than as active participants. Each of these groups had particular experiences which would cause them to respond differently to the post-war situation, and this would lead to considerable friction within surrealist circles (not simply linked to those who came to reconstitute the group around Breton). But all of these factions viewed the war principally as a fight against the greater evil of fascism and considered that the primary task after its defeat to be the re-assertion of human values and the restoration of human dignity. $\frac{\sqrt{ }}{}$ Not so Henein.

Of course, Henein also saw fascism as the principal enemy, but he could not detach it from a more generalized evil that he located within European culture as well as within the human sensibility itself. It was not for him a matter of the restoration of values or even the creation of new ones; it was rather a question of determining the nature of the cancer of which fascism was only the most virulent and manifest form.

We can see this in Henein's major statement about the war, his pamphlet Prestige of Terror, written in white heat in its immediate aftermath, in the days following the Japanese surrender, and published on 17 August 1945. This neglected document, one of the most extraordinarily far-sighted of the time, refuses to see any cause for celebration in the allied victory. Quite the contrary: this victory had merely concretized what fascism had initially put in place, and Saint George might even prove to be worse than the dragon he had conquered: "The values presiding over our conception of life and which spare us here and there the islands of hope and intervals of dignity, are quite methodically devastated by the events in which, to cap it all, we are invited to observe our victory, to welcome the eternal destruction of a dragon that is always reborn" (Euvres 476). This was made tangible by the decision taken to drop atomic bombs on the cities of Hiroshima and Nagasaki, something Henein saw as the culmination of a progressive dehumanization that began when Italian aviators used mustard gas in the campaign in Ethiopia, was continued by the bombing of Guernica in Spain and by the Blitz inflicted upon Britain, but was then taken up in response by the saturation bombing by the allies of German and Japanese cities: "we are currently witnessing," Henein argued, "a penetration of Hitlerian political behavior into the ranks of democracy" (Euvres 481). This conferred upon states the 'right to terror', making them criminally implicated in the very terror which they may initially have thought they were acting against. In other words, the State itself had 
become a terrorist, something we might reflect upon more in viewing the history of the world in the intervening years and ponder whether it has been 'terrorism,' in one form or another, rather than 'totalitarianism' as such, that has been the dominant weapon of repression by regimes since the Second World War, something making any claim to 'democracy' hollow.

What is most remarkable about this perception is that Henein was not arguing from any humanist perspective. It was not the incredible suffering and loss of life that these actions wrought on civilian populations that Henein saw as being most criminal. Rather it was the mentality that had made the actions conceivable in the first place, a mentality that went beyond even the perception that 'the end justifies the means' to enter a domain in which the means themselves became their own justification, in and beyond whatever consequences they might have for humanity itself. In this respect Henein here anticipates some of the arguments that would later be developed by Hannah Arendt, and even more specifically by Giorgio Agamben, about the ways in which totalitarianism has increasingly come to infect democracy. Indeed, Henein explicitly tells us that with Hiroshima the modern State has become a terrorist State and so has abrogated any of the moral legitimacy it formerly had to act against acts of terrorism directed towards it.

The fact that the French surrealists had largely remained silent at this time about the nuclear threat and the consequences of Hiroshima must also have been a factor feeding Henein's disillusion. Gavin Parkinson speculates that the surrealists' reluctance to enter the anti-nuclear debate after the war, and more particularly to engage with the consequences of the Hiroshima attack, may have been due to the fact that the main opposition to nuclear warfare at that time came from the churches, with which the surrealists would never be able to bring themselves to associate in a common cause of any sort (206). This may in fact account for why Henein was so disturbed by the anti-religious tract $A$ la Niche..., something he perhaps regarded in the context of the time as a kind of fiddling while Rome burned.

Another point of contention raised by Alexandrian was the surrealists' decision to support the foundation of the State of Israel. When an objection was made within the group that this contradicted the fundamental surrealist opposition to the idea of the State, Breton justified it on the conventional ground that something had to be done to prevent future anti-Semitic pogroms, a rare moment of political miscalculation on Breton's part. Neither Henein nor Younane were invited to contribute to this debate, a serious oversight, to say the least, since they were the two surrealists who would have had most insight into the likely consequences. It is not difficult to see that Henein would have seen this as a narrowing of surrealist horizons, a surrendering to short term contingency with no regard for the long term consequences. Furthermore, he could hardly have regarded the establishment of the State 
of Israel as anything other than further confirmation of what he had argued about the 'Nazification' of democracy, especially when considering the displacement of the Palestinian population this would inevitably involve.

Henein's perspective has to be understood in relation to his situation as an exile. It is common to speak him as a 'cosmopolitan', but in a sense he was the opposite of a cosmopolitan as, perhaps, the exile always is. The true cosmopolitan is someone who is comfortable anywhere; the true exile, in contrast, is uncomfortable everywhere. We might, for instance, compare Henein with another participant in surrealism, the Mexican Octavio Paz, who seems to have been a genuine cosmopolitan: moving between Mexico, India and Paris, we never get any sense of displacement in his writings. Rather, he was, so to speak, 'Mexican in Mexico, Indian in India, Parisian in Paris.' Henein, however, was restless wherever he was, never quite comfortable with his surroundings.

Not that he would have necessarily chosen otherwise. Exile was a way of life for Henein, which he may for the most part have welcomed for himself. Nevertheless, he did perceive its negative aspects, and there is within his writing an underlying longing for a home, even if at the same time he knows this would not satisfy him. The tension this created within him still seems to have given him an acute insight into the evils of displacement when it was the result not, as in his case, of a relatively privileged movement from place to place, but was enforced as a result of economic, political or ideological need or expediency. Exile was one thing; displacement another, and the latter was infinitely worse, because the exile at least has the possibility of return, while the displaced are torn from everything they have known, not only from their homes but also from their traditions and the sense of belonging that the notion of 'rootedness' suggests. Forced to start everything again from scratch, some may be able to treat this as an opportunity for fresh beginnings, but for those with most to lose it constitutes an irreparable trauma. In seeing displacement as one of the central evils of the twentieth century, Henein was extraordinarily far-sighted in his perspective:

what is displaced is not simply the physical being but is, in the same capacity, the internal existence of each, the sum of their dreams, desires and refusal. Forced migration is only the geographical expression of the general moulding of man. The visible tragedy is only the apparent manifestation of an incessant and desperate work which is being continually effected on the human material. The loftily perfected technology of power allows the man-unity to be disconnected, to be pulled together, then cast out again into some or other circuit. (L'Esprit frappeur 77)

In this respect, one can already perceive in Henein's work an anticipation of the issues that Edward Said would bring into global perspective with the publication in 1978 of his book Orientalism. Like Said, Henein recognised an 
elemental conflict between the idea of the West and that of the Orient, but to a far greater extent than Said he was aware of the extent of complicity contained within this relation: the critique of the West can only be made, he says, "using tools furnished by the West itself" (Euvres 534). Rather than trying to resist this or find an alternative to it, he seems to imply, one needs to understand the nature of these tools and transform them, utilizing the great weapon that the West has given to the rest of the world: the possibility of doubt. This possibility of doubt is crucial to our understanding of Henein which, tied in at the same time with the experience of exile as well as that of surrealism, allowed him to grasp a sense of humanity as a single consciousness, albeit one that is broken up into many small pieces, from which perspective it was necessary for us to try to see beyond the visible and the dimensions of one's own life.

Henein published prolifically, but chiefly in journals or ephemeral pamphlets and publications. He published no substantial volumes during his lifetime, and his final book, Le Seuil interdit (The Forbidden Threshold), appeared in 1956, fully seventeen years before his death. We only really know his work, therefore, from the texts that have been gathered from this fragmentary material, which was finally put together in substantial form as Euvres, published in 2006.

However, his most extraordinary book is perhaps L'Esprit frappeur, which appeared in 1980. A collection of notes published after his death, it is not clear whether this was the form in which they were left by Henein or whether they were compiled by Boula from more extensive notebooks. Whatever the case, it has a remarkable internal cohesiveness and has something in common with the diary of another permanent exile, the Polish writer Witold Gombrowicz, in its acerbic and incisive nature. Covering the years from 1940 until just before his death in 1973, the title translates as "poltergeist" or "striking (rapping) spirit". Was this title Henein's or did Boula add it? Perhaps it was Boula's idea - a final act of love and complicity, giving emphasis to what Henein would no doubt wish: to come to us from elsewhere, knocking hard and still causing disturbances in this world. In any event, it seems singularly appropriate.

Reading these notes, it is sometimes difficult to believe that Henein was writing as long ago as the fifties and sixties, as concern about such current issues as surveillance, loss of personal identity, technological determinism and social and cultural displacement is present throughout the book. He is particularly contemptuous of what he calls "drillers of identity" (L'Esprit frappeur 114) who use technology to classify our emotions and photograph our sensibility. His warnings are particularly prescient in the emphasis he places on the need to maintain the mystery of our being. "The last resource of contemporary man", he says, "is not to say who he is" (Euvres 114). Yet today this "last resource" has been definitively withdrawn as we are 
impelled each day to make ourselves more transparent, often without our knowledge, through endlessly invasive techniques of checking and surveillance (themselves forms of terrorism against the person as foreseen by Henein: "terror has become the psychiatry of the masses" (Euvres 535)), and no one now can refuse to say who he is. In consequence, "the problem of free choice is precipitously conjured away, and humanity finds itself faced with a group of commandments if not entangled in a net of conditioning of which each thread is stretched for it" (Euvres 852). Henein thus envies Socrates, saying that he got off lightly by only being forced to drink hemlock instead of being sent for psychiatric help or forced to fill in endless forms "baring his antecedents, his intentions, his morality, his activities, his degree of loyalty towards one or another pretentious or oppressive entity" (L'Esprit frappeur 114). The aim of such procedures, he says, is to reduce teaching, among other things, to such an extent that it would become 'the art of communicating nothing'. Could there be a more prescient statement of what education, in particular, would have been transformed into before the century was up?

Like Breton and most other surrealists, Henein did not believe in liberation or release from the human condition. In L'Esprit frappeur he notes that "the spirit of liberation and that of coercion are possible accomplices, having a latent kinship" (56). It was rather to the rallying cry of liberty that Henein was drawn, assuming the distinction between liberation and liberty that Breton made in Arcane 17. In his essay, "Freedom as Nostalgia and as Project," Henein echoes Breton: "liberation is a labor; liberty a state, a sovereign disposition of existence." And the result of labor is always more labor, while the aim of liberty has to be the end of labor as "a non-partisan exaltation of life" (Euvres 848). What is at stake here is the very constitution of the human at a time when the central problem is "no longer [one] of development but of preservation." Furthermore, "when economic fact becomes the absolute, all the pains of work are by the same token nothing but pains [...] by placing production as the good at any price means at the price of humanity" (Euvres 852). It has become, he argued, no longer possible to speak of "citizens"; one should speak of the "administered." Fifty years on, could our current dilemma be more starkly stated?

The denial of freedom from a surrealist perspective is essentially a denial of ourselves, a capitulation to the alienation of life, something which places us in a position by which we can be reduced "to the level of merchandise to be manipulated, treated, sold off like a sack of coal" (Euvres 850). Placed, that is, in a situation in which we are simply considered to be part of a pool of 'human resources,' to be utilized as and when required. In this situation, freedom itself loses its meaning as it becomes appropriated by and assigned to the State. It is thereby transformed into a product, another of the luxury goods that the State thinks it can dispense according to its own will and determination. In opposition to this, Henein argues that freedom needs to 
be re-inscribed within our lifelines as it is recognised and promulgated as "a sovereign disposition of existence" (Euvres 848). For all surrealists, I think, freedom is not something to be attained, but rather something to be recovered or, more accurately, recognised. In many ways, this explains the prestige of the Marquis de Sade within surrealist thought, because he was the man more than any other who defied the efforts of the world to tie down the notion of freedom: even enchained, Sade showed, a man could remain free in his thoughts and in his imagination.

Freedom is a natural state, so much so that it is only perceived when one becomes aware that it might be taken away; it cannot be given or gained, but can only be lost or removed, often in the name of freedom itself. We need, therefore, to be on our "guard concerning the traps which are extended to us in its name" and in particular to be aware that "freedom to bite deforms the jaws and results in a rather disturbing transformation of the physiognomy, and even of the personality itself" (Euvres 79). Henein is here thinking of the way the State dispenses the freedom to denounce, turning citizen against citizen and deforming freedom. This makes it necessary for each person, to the extent that it is given to him or her, to embody this freedom on behalf of all, a task Henein took for himself by revealing the nature of our entrapment. We are, he argued, caught between the eagle's nest and the mousetrap, that is, we seek the heights (especially through technology) where we will be freed from ignorance and lack of possibilities, but in rising higher we create fresh snares that entrap us even more than before; this means that we lose track of where we are, which is always "ahead of ourselves" (Euvres 859). Furthermore, anticipating Marcuse's notion of repressive tolerance, Henein notes how the State plays upon such contrary forces, wanting to be able to manufacture both the rain and the umbrella. Thus "the State invented subversion because it wanted to offer itself a wake-up call" (L'Esprit frappeur 119).

Henein sought out the most intractable of individuals as his confreres, a motley crew of correspondents that included Henri Calet, Edmond Jabès, Nicolas Calas, Raymond Abellio, Henri Michaux, André Malraux and, most surprising of all, Louis-Ferdinand Céline. These men seem to have had little in common with one another and several of them had very different social and political views from those of Henein. One imagines that to a great extent he sought them out precisely for their dissimilarity and the challenge they offered to his own views. For someone as morally concerned as Henein, it seems strange that he should be sympathetic to the compromised Céline, the avowed anti-Semite, misanthropic and even neo-fascist in his outlook, the man the surrealists in 1957 dismissed as being "entirely dominated by rage, sordid calculation and cowardice" (see Fijalkowski and Richardson 164), but Henein seems to have admired all of those who were prepared stand out against the crowd, even if he strongly disagreed with their actual standpoints. 
What mattered to him here, I think, was the notion of communication, the possibility for a challenging of his own views by those of others. In his thinking, however, he seems closest to someone with whom he surprisingly never appears to have corresponded: Georges Bataille, although he did often write about him and they collaborated on Troisième convoi. Like Bataille, Henein regarded knowledge with deep suspicion, at least the sort of knowledge that modern society places its faith in: that accumulation of knowledge that supposedly "empowers" us purely because it has increased. The race to gain more knowledge, he tells us, is like a gold rush and leads to an excess of knowledge within which we lose ourselves instead of becoming wiser (L'Esprit frappeur 35). One needs to combat this with what he terms "subversive resignation," a notion one imagines he must have drawn from his reading of Bataille (he wrote this passage in 1946, at the moment he was reviewing Bataille's L'Expérience intérieure and Le Coupable).

Henein similarly evokes the notion of the sacred and its absence in the modern world as constituting an elemental loss which tears living from itself: "The sacred is the intimate gleam of an instant, a sort of unformulatable internal dawning which communicates to other people without passing through the realm of signs. Overall, it would be a matter less of a communication than of a shock. Any final condition, in its completion, ultimately compromises the future of the sacred" (Euvres 285). Embodied in the instant, the sacred is essential to maintain the sense of living as something eternal.

This refusal of the final condition, central, I think, to surrealism and what ultimately separates it from the Hegelian philosophy which conditions it in so many other crucial ways, also determines its attitude towards the sacred which, as Henein here makes clear, has to be considered immanent to our being and as functioning against the urge towards the eagle's nest while being alert to the snare set by the mousetrap.

Georges Henein may have early on recognised that life is surrounded by the walls of an empire whose scope is infinite, but he refused to surrender to any sense of despair. If the walls of this empire cannot be scaled, one can still experience the vertigo of strolling in the extent of its margins. Through his voice he has transmitted to us messages whose urgency can still touch us today.

\section{Notes}

1. His lifelong companion, Ikbal el Alaily (known as Boula), was the granddaughter of Egyptian national poet and 'prince of Arab poets' Ahmed Chawky. He met her in 1939, but they were only able to marry in 1955.

2. This letter, or at least the draft which was found in Henein's papers, was published by Sarane Alexandrian (see Georges Henein 53-55). Breton is very often portrayed by critics as authoritarian, whereas in this letter Henein takes him to 
task for being over-indulgent. Roger Caillois had made the same criticism in his own resignation letter to Breton some fourteen years earlier, and indeed if the history of surrealism is examined objectively in its own terms it is difficult to see how the accusation of authoritarianism against Breton could ever be seriously sustained. As Alexandrian points out: "The surrealists expected everything of surrealism, and hoped for the impossible from André Breton: this explains the violence of their refusal when they felt that this movement had become subject to contradictions (like all movements) and that Breton was fallible (like all people)" (Georges Henein 56).

3. Both of these tracts are to be found translated in Fijalkowski and Richardson (42-48; 152-54).

4. It is nevertheless difficult to understand why Younane and Henein should have had reservations about this tract, which was not some facile anti-clerical gesture but responded to a very real issue: the way the church was re-positioning itself at the time so as to subsume atheist and anti-Christian sentiment (even surrealism) to itself as examples of rebellion proving by that very opposition the truth of Christianity.

5. The only exception to this was Troisieme convoi, the short-lived and rather obscure group (to which Henein belonged) constituted by Michel FardoulisLagrange, Jean Maquet and Georges Bataille. Henein in fact conceived of this enterprise as constituting a Breton-Bataille conjunction (see L'Esprit frappeur 69). Bataille, indeed, appears to have been one of the few people in Europe at this time to have realised the wider significance of Hiroshima in terms similar to those of Henein.

\section{Works Cited}

Alexandrian, Sarane. Georges Henein. Paris: Seghers, 1981. Print.

- Le Surréalisme et le rêve. Paris: Gallimard, 1974. Print.

Breton, André. Manifestoes of Surrealism. Trans. Richard Seaver and Helen R. Lane. Ann Arbor: U of Michigan P, 1969. Print.

El Janabi, Abdel Kader. The Nile of Surrealism: Surrealist Activities in Egypt, 19361952. Paris: Arabie sur Seine, 1991. Print.

Fijalkowski, Krzysztof, and Michael Richardson, ed. Surrealism Against the Current: Tracts and Declarations. London: Pluto P, 2001. Print.

Henein, Georges. Déraisons d'être. Paris: Corti, 1938. Print.

- L'Esprit frappeur: Carnets 1940-1973. Paris: Encre, 1980. Print.

_. La Force de saluer. Paris: Editions de la Différence, 1978. Print.

. Euvres: Poésies, récits, essais et articles. Ed. Pierre Vilar. Paris: Denoël,

2006. Print.

- Pour une Conscience sacrilège. Cairo: Editions Masses, 1945. Print.

- Prestige de la terreur. Cairo: Editions Masses, 1945. Print. 
Qui êtes vous, Monsieur Aragon? Cairo: Editions Masses, 1945. Print.

. Le Seuil interdit. Paris: Mercure de France, 1956. Print.

LaCoss, Don. Art and Liberty: Surrealism In Egypt. (n.d.) Available at http://www. egyptiansurrealism.com/index.php?/contents/art-and-liberty-surrealism-inegypt/. Web. 13 Sept. 2012.

- Egyptian Surrealism and 'Degenerate Art' in 1939. (n.d.) Available at http:// interactivist.autonomedia.org/node/13908. Web. 13 Sept 2012.

Parkinson, Gavin. Surrealism, Art, and Modern Science: Relativity, Quantum Mechanics, Epistemology. New Haven: Yale UP, 2008. Print.

Copyright (C) 2013 Michael Richardson 